\title{
Detection of human cytomegalovirus by the polymerase chain reaction in immunosuppressed and immunocompromised patients
}

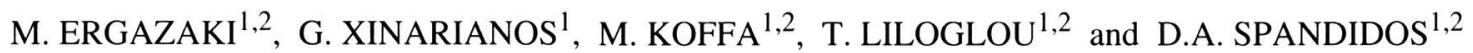 \\ ${ }^{1}$ National Hellenic Research Foundation, Institute of Biological Research and Biotechnology, Athens 116 35; \\ ${ }^{2}$ University of Crete, Medical School, Laboratory of Clinical Virology, Heraklion, Greece
}

Received March 15, 1994; Accepted April 14, 1994

\begin{abstract}
Infections caused by Human Cytomegalovirus (HCMV) are very common in patients who undergo immunosuppression or immunocompromisation. The techniques used for routine HCMV detection are timeconsuming and lack specificity and sensitivity. The ability of the Polymerase Chain Reaction (PCR) to amplify HCMV DNA from clinical samples of the patients is a valuable diagnostic tool for the detection of HCMV in the early stages of the infection. We used a pair of primers to amplify a 435 bp region of the immediate early-1 gene, to detect HCMV DNA in clinical samples from patients at high risk for HCMV infection. We found HCMV in the following type of patients: 6 out of 20 in immunosuppressed, 11 out of 31 in immunocompromised, 5 out of 8 in pregnant women, 4 out of 25 in patients with high anti-CMV IgM and IgG titres, 1 out of 2 in patients with kidney failure, and 6 out of 14 in patients with opthalmic disorders. Sixty-seven specimens, which were found to be negative for CMV by the PCR technique, were used to inoculate human fibroblast monolayer cultures and PCR was performed to the DNA extracted from the cultured cells. Only in 1 out of the 67 cases HCMV DNA was detected.
\end{abstract}

\section{Introduction}

HCMV is a viral pathogen of major importance belonging to the family of Herpesviridae. The primary disease is rare but infections caused by HCMV are common. HCMV is associated with silent infections which can be activated in immunosuppressed and immunodeficient patients, pregnant women and lowbirthweight neonates (1).

Most current techniques for HCMV detection are based on serology such as latex agglutination and enzyme-linked

Correspondence to: Professor D.A. Spandidos, National Hellenic Research Foundation, Institute of Biological Research and Biotechnology, 48 Vas. Constantinou Avenue, Athens 116 35, Greece

Key words: human cytomegalovirus, polymerase chain reaction immunosorbent assay (ELISA). Active HCMV infection can be determined by cell culture, testing for cytopathic effect (CPE). However, both approaches have significant disadvantages. The tissue culture procedures are timeconsuming and expensive while the detection of anti-CMV antibodies in immunosuppressed and immunodeficient patients require high level of expertise (2).

PCR is a rapid and sensitive method which has many diagnostic applications in medical practice $(3,4)$. The use of PCR for the detection of HCMV viral DNA in clinical specimens (e.g. blood, urine, bronchoalveolar lavage) has been reported by many workers $(5,6)$.

We used PCR to amplify a 435 bp long sequence from the immediate early- 1 gene of HCMV in blood samples from immunosuppressed and immunodeficient patients, pregnant women, patients with retinitis, and keratitis, and patients with high anti-CMV IgM and IgG titres.

To increase the sensitivity of the method we combined our preliminary results from PCR with those obtained from cell culture of the initial samples and PCR amplification of the DNA extracted from the culture.

\section{Materials and methods}

\section{DNA extraction}

Blood. Leucocytes were isolated from $3 \mathrm{ml}$ blood using Lymphoprep (Nycomed AS) and lysed with the addition of $400 \mu \mathrm{l}$ TES buffer containing $100 \mu \mathrm{g} / \mathrm{ml}$ Proteinase K. After incubation at $37^{\circ} \mathrm{C} \mathrm{O} / \mathrm{N}$ samples were extracted once with phenol and once with phenol/chloroform. DNA was precipitated with the addition of $20 \mu \mathrm{l} 5 \mathrm{M} \mathrm{NaCl}$ and $1 \mathrm{ml}$ ethanol. DNA was recovered by centrifugation at $11,000 \mathrm{rpm}$ for $15 \mathrm{~min}$ at $4^{\circ} \mathrm{C}$, washed once with $70 \%$ ethanol and resuspended in $100 \mu \mathrm{l}$ of double-distilled water.

Cultured cells. Cells were trypsinized and collected by centrifugation at 1,600 rpm for $5 \mathrm{~min}$. Pellets were then lysed with $2 \mathrm{ml}$ lysis buffer ( $10 \mathrm{mM}$ EDTA, $10 \mathrm{mM}$ Tris-HCl $\mathrm{pH}$ $7.8,150 \mathrm{mM} \mathrm{NaCl}$ and $0.5 \%$ SDS) containing $100 \mu \mathrm{g} / \mathrm{ml}$ Proteinase $\mathrm{K}$ and incubated at $60^{\circ} \mathrm{C}$ for $60 \mathrm{~min}$. Equal quantity of Proteinase $\mathrm{K}$ was added followed by incubation at $60^{\circ} \mathrm{C}$ for another $60 \mathrm{~min}$. Samples were extracted once with phenol and once with phenol/chloroform. DNA was precipitated with the addition of $100 \mu l 5 \mathrm{M} \mathrm{NaCl}$ and $5 \mathrm{ml}$ 


\section{HCMV genome}

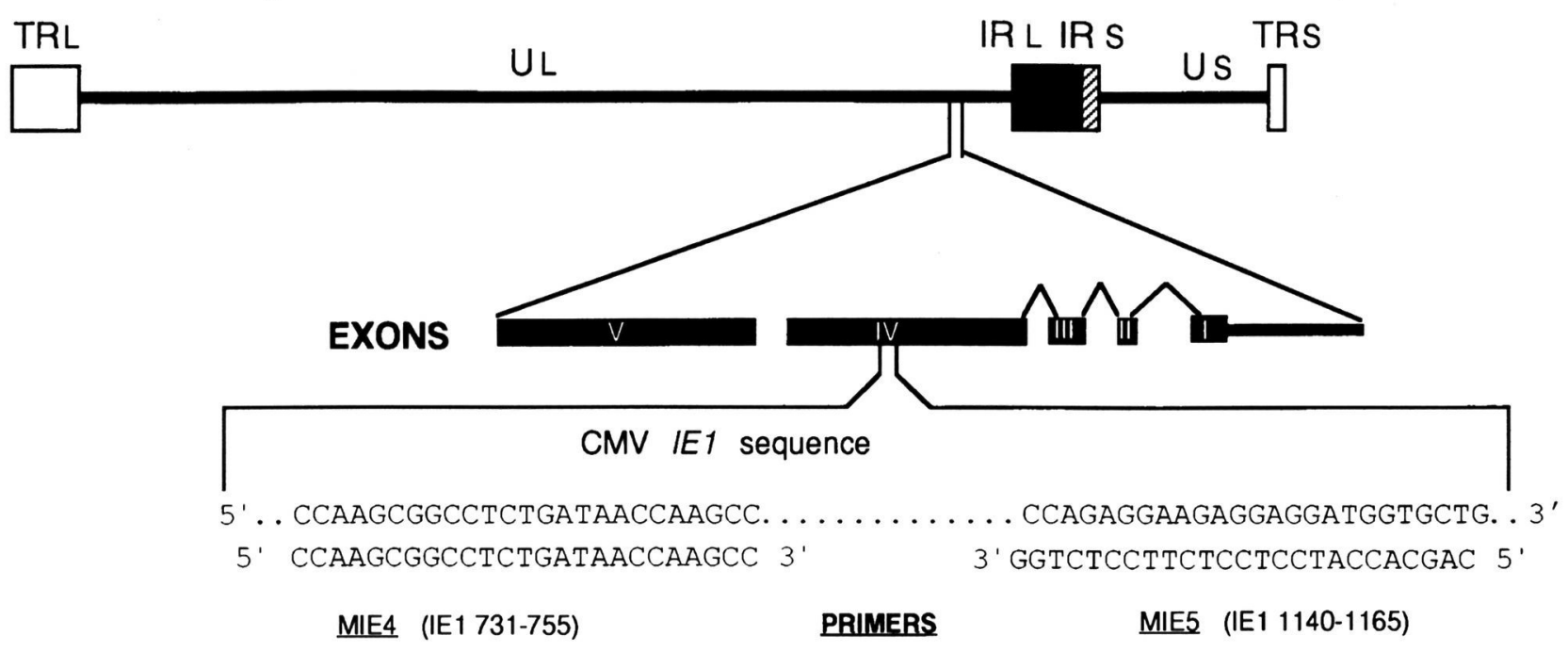

PCR amplification

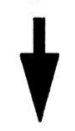

5'CCAAGCGGCCTCTGATAACCAAGCC. ....GGTCTCCTTCTCCTCCTACCACGAC 3'

\section{PCR product (435bp)}

Figure 1. HCMV genome and related primers.

Table I. Summary of results on the detection of HCMV by PCR.

Study cases

\section{CMV}

positive
2. Patients with lymphoma

3. Patients with malignancies

4. Kidney transplant patients

5. Heart transplant patients

6. Pregnant women $\mathrm{CMV}$ IgM and IgG titres

8. Patients with kidney failure

9. Patients with retinitis and keratitis

\section{AIDS patients}

7. Patients with high anti-

Number of
patients $\quad \begin{gathered}\text { CMV } \\ \text { positive }\end{gathered}$

\begin{tabular}{rl}
10 & 5 \\
11 & 5 \\
10 & 1 \\
10 & 3 \\
10 & 3 \\
8 & 5 \\
25 & 4 \\
2 & 1 \\
14 & $6^{\mathrm{a}}$ \\
& \\
\hline 100 & 33
\end{tabular}

a 2 blood and aqueous humour; 4 blood. ethanol. DNA was recovered by centrifugation at $11,000 \mathrm{rpm}$ for $15 \mathrm{~min}$ at $4^{\circ} \mathrm{C}$ and resuspended in $40 \mu 1$ of doubledistilled water.

Aqueous humour. $\mathrm{NaOH}$ was added to final concentration $0.1 \mathrm{~N}$ and samples were boiled for $5 \mathrm{~min}$. Samples were extracted once with phenol and once with phenol/chloroform. DNA was precipitated as described above.

Cell culture. MRC-5 human embryonic lung fibroblasts were maintained in DMEM/F12 (Gibco BRL) containing 10\% fetal calf serum and antibiotics (7).

Subconfluent cell monolayers were infected with $10 \%$ of the initially isolated leucocytes and incubated at $37^{\circ} \mathrm{C}$ with $5 \% \mathrm{CO}_{2}$ for 48 hours.

Oligonucleotides and PCR amplification. We used a pair of primers, termed MIE-4 and MIE-5, which have been previously described $(8,9)$ to amplify a $435 \mathrm{bp}$ long sequence from the immediate early- 1 gene of HCMV. The primers along with the HCMV IE-1 sequence are schematically presented in Fig. 1.

500 ng DNA of each sample was amplified in a volume of $100 \mu \mathrm{l}$ containing $200 \mu \mathrm{m}$ of dNTPs, 50 pmoles of each primer, $20 \mathrm{mM}$ Tris- $\mathrm{HCl}(\mathrm{pH} 8.4), 50 \mathrm{mM} \mathrm{KCl}, 2 \mathrm{mM}$ $\mathrm{MgCl}_{2}$ and 2.5 units Taq polymerase (Gibco BRL). Amplification was performed in a thermal cycler (Perkin Elmer Cetus) using the following conditions: denaturation at $94^{\circ} \mathrm{C}$ for $50 \mathrm{sec}$, annealing at $62^{\circ} \mathrm{C}$ for $30 \mathrm{sec}$ and extension 


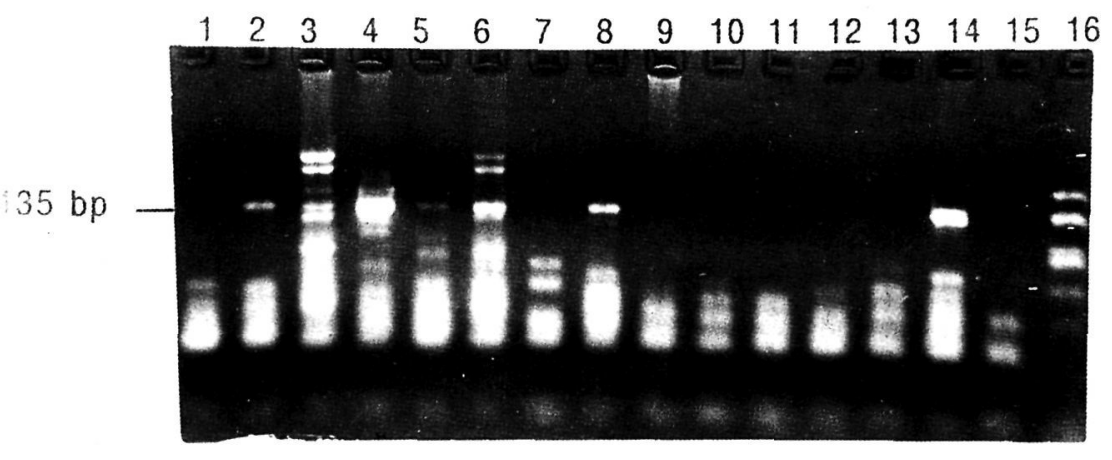

Figure 2. Detection of HCMV DNA by PCR. Amplification products were electrophoresed through a $2 \%$ agarose gel. Lane 1: negative control, lanes $2,3,4$. 5, 6, 8: positive samples, lanes 7, 9, 10,11: negative samples, lane 15: negative control from CMV cell culture, lane 14: positive sample from CMV cell culture, lanes 12, 13: negative samples from CMV cell culture, lane 16: pUC18/HaeIII molecular marker.

at $72^{\circ} \mathrm{C}$ for $50 \mathrm{sec}$, increasing the extension time by $1 \mathrm{sec}$ per cycle. Samples were subjected to 40 cycles of amplification.

Twenty $\mu l$ of the amplification products was analysed on a $2 \%$ agarose gel and visualized under UV illumination after staining with ethidium bromide.

\section{Results}

We examined 100 patients at high risk for CMV infection. Our results are summarised in Table I. HCMV DNA was detected in 33 out of the 100 examined patients. The presence of HCMV was judged from the amplification of a 435 bp long sequence (Fig. 2). HCMV DNA was detected in 5 out of 10 AIDS patients, 5 out of 11 patients with lymphomas (Hodgkin's and non-Hodgkin's), 1 out of 10 patients with malignancies (e.g leucemia, myelodysplastic syndrome), 3 out of 10 kidney transplant patients, 5 out of 8 pregnant women, 4 out of 25 patients with high anti-CMV IgM and IgG titres, 1 out of 2 patients with kidney failure, 6 out of 14 patients with retinitis, and keratitis. Sixty-seven patients who were found to be CMV negative by the PCR were further examined with cell culture of the initial sample and application of the PCR in the DNA extracted from the culture. Only one of the examined samples was found positive after cell culture. This patient suffered from retinal necrosis and was found to be CMV positive by the PCR in the aqueous humour but negative in the blood. However, CMV was detected in his blood after cell culture and PCR amplification of the extracted DNA.

\section{Discussion}

CMV detection using traditional methods is hampered by low sensitivity and the long lag time between testing and obtaining a positive result. With the increase in the number of immunodeficient and immunocompromised patients being treated, CMV has become an important cause of morbidity and mortality in these patients and proper treatment requires prompt and accurate diagnosis. A rapid and sensitive method of viral DNA detection would be useful in identifying blood products and organs capable of transmitting infection, thereby increasing prevention (10). PCR has been proved to be sensitive and rapid as well as accurate and specific for the detection of small amounts of viral genomes $(11,12)$. PCR does not depend on the immune response of the patient which can be defective due to postoperative pharmaceutical immunosuppression or due to immune disorders. Comparison of our preliminary negative results with the results obtained after PCR DNA amplification of the cell culture shows that PCR is a very accurate and sensitive method for the detection of HCMV in clinical specimens. Moreover, PCR does not have the drawbacks of previous methods and its application as a routine diagnostic tool in clinical virology is of major importance. The sensitivity and the accuracy of PCR in the detection of active infections makes this technique a powerful tool in diagnostic virology and is expected to reduce the morbidity and mortality rate in susceptible patients with higher risk for HCMV infection (e.g. multiple transfused, transplant patients, and immunodeficient patients).

\section{References}

1. Smith KL: PCR detection of cytomegalovirus: A review. Br $\mathbf{J}$ Haematol 84: 187-190, 1993.

2. Rasmussen L, Kelsall D and Nelson R: Virus specific IgG and $\operatorname{IgM}$ antibodies in normal and immunocompromised subjects infected with cytomegalovirus. J Inf Dis 145: 191-199, 1982.

3. Eisenstein BI: The polymerase chain reaction. A new method of using molecular genetics for medical diagnosis. N Engl $\mathbf{J}$ Med 322: 178-183, 1990.

4. Erlich HA, Gelfand D, Sninsky JJ: Recent advances in the polymerase chain reaction. Science 252: 1643-1650, 1991.

5. Shibata D, Martin WJ, Appleman MD, Causey DM, Leedom JM and Arnheim N: Detection of cytomegalovirus DNA in peripheral blood of patients infected with human immunodeficiency virus. J Inf Dis 158: 1185-1192, 1988.

6. Burgart LJ, Heller MJ, Reznicek MJ, Greiner TC, Teneyck CJ and Robinson RA: Cytomegalovirus detection in bone marrow transplant patients with idiopathic pneumonitis. A clinopathologic study of the clinical utility of the polymerase chain reaction on open lung biopsy specimen tissue. Clin Microb Inf Dis 96: 572-576, 1991.

7. Mazeron MC, Benjelloun B, Bertrand C, Pons JL and Perol Y: Comparison of MRC-5 and continuous cell lines for detection of cytomegalovirus in centrifugation cultures. J Virol Meth 39: 311-318, 1992

8. Demmler GJ, Buffone GJ, Schimbor CM and May RA: Detection of cytomegalovirus in urine from newborns by using polymerase chain reaction DNA amplification. J Inf Dis 158: 1177-1184, 1988.

9. Smith KL, Cobain $T$ and Dunstan RA: Removal of cytomegalovirus DNA from donor blood by filtration. Br J Haematol 83: 640-642, 1993 
10. Bevan IS, Daw RA, Day PJR, Ala FA and Walker MR: Polymerase chain reaction for detection of human cytomegalovirus infection in a blood donor population. $\mathrm{Br} \mathbf{J}$ Haematol 78: 94-99, 1991.

11. Nikolaidou A, Liloglou T, Malliri A, Ergazaki M, Tiniakos G, Tiniakos D and Spandidos DA: Detection of hepatitis B virus DNA and mutations in K-ras and p53 genes in human hepatocellular carcinomas. Int J Oncol 3: 593-596, 1993.

12. Rogers BB, Josephson SL and Mak SK: Detection of herpes simplex virus using the polymerase chain reaction followed by endonuclease cleavage. Am J Pathol 139: 1-6, 1991. 